\title{
Press Coverage of Climate Change Issues in Nigeria and Implications for Public Participation Opportunities
}

\author{
Herbert E. Batta ${ }^{1}$, Ashong C. Ashong ${ }^{1}$, \& Abdullahi S. Bashir ${ }^{2}$ \\ ${ }^{1}$ Department of Communication Arts, University of Uyo, Nigeria \\ ${ }^{2}$ Department of Information Technology, Modibbo Adama University of Technology, Yola, Nigeria \\ Correspondence: Herbert E. Batta, Department of Communication Arts, University of Uyo, Uyo, Akwa Ibom \\ State, Nigeria. Tel: 234-802-344-4791. E-mail: heribertobat@yahoo.com
}

Received: December 8, 2012 Accepted: January 14, 2013 Online Published: January 17, 2013

doi:10.5539/jsd.v6n2p56

URL: http://dx.doi.org/10.5539/jsd.v6n2p56

\begin{abstract}
Nigeria faces a lot of environmental problems such as extensive gas flaring, deforestation, and desertification with serious consequences on climate change. How are these issues covered and framed by Nigerian newspapers? Content analysis of systematically sampled, 438 issues from 4380 issues of four purposively selected dailies between 2007 and 2009 shows dominance of climate politics/economics issues (61.2\%), foreign sourcing of reports $(63.4 \%)$, straight news formatting of reports $(83.6 \%)$ and framing in terms of mitigation $(55.2 \%)$. Mitigation efforts aim to reduce or prevent emission of greenhouse gases implicated in climate change. We conclude that coverage and framing constrain opportunities for popular participation in climate change discourse. To improve the situation, Nigerian newspapers should broaden the scope of climate change coverage and framing, widen local sourcing of reports, diversify the formats of reporting, and frame the issues more in the mould of adaptation (activities and measures to reduce risks posed by climatic changes) to boost involvement of people in climate change discourse through monitorial, supportive and collaborative strategy in agenda setting agenda.
\end{abstract}

Keywords: media, West Africa, climate change, discourse, framing

\section{Introduction}

Environmental issues have become important in the world for decades. National governments as well as the United nations have taken steps to increase the level of awareness and attention paid to problems of air and, water pollution, deforestation, desertification, green-house gas emission, global warming, climate change, etc. These problems have necessitated a number of summits, conferences, conventions and declarations. The Rio declaration on environment is one such example. Adopted by 178 nations at the United Nations Conference on Environment and Development in Rio-de Janeiro, Brazil; Principle 10 underscores the importance of awareness, access to information, and participation of the people in matters that affect them in relation to the environment. Principle 22 underlines the critical role of indigenous people and their communities which should be enabled to participate effectively in the achievement of sustainable development (www.unep.org/documents/default.asp).

These principles are very relevant to Nigeria not only because it is a signatory to the Rio declaration, but because the emphasis placed on access to information and the importance of awareness cast a role for the media of communication in Nigeria including newspapers. Nigeria occupies a sizeable portion of the earth's land and water space. It is a major hydrocarbon and gas producing nation with a thick population of over 150 million people mostly engaged in subsistent farming, fishing, and grazing. What these mean is that Nigeria and Nigerians are bound to affect and be affected by climate change. Tribune.com.ng (2012) documents that the effects of climate change in Nigeria include flooding of many parts, erosion, unpredictable weather, continuous incursions of the desert into the northern parts of the country, decline of fishing stocks, disappearance of rare animals from the forests, etc. Umeje (2010) observes that the media in Nigeria appear to be relatively aloof in matters of creating awareness on climate change issues, that Nigeria risks the ravages of global challenges posed by climate change. In his assessment, the Nigerian media seem to lag behind in awareness campaign on climate change and tend to leave it for individuals. Umeje's position is that most Africans are not informed on climate change and that the media have the urgent duty to assume a prominent role in creating awareness on the issues. 
However, according to climate change challenge.org (2012), the possession of accurate and complete understanding of information on climate change is not a prerequisite for concern. It agrees that a lack of citizen understanding regarding the basics of climate science exists worldwide. It points out that the media can play key role in mitigating the effects of climate change. This happens because media reports have a relationship on the way people reason and behave. The media help to close the information gap by enlightening people on environmental issues, and assisting in simplifying the technical language of climate science for the people with basic or average education.

One of the ways through which the media inform and educate the public about issues is framing and agenda setting. According to Taylor (2011), framing is important in terms of how a message is shared and how it is received. Also, frames and agenda regulate how the society shapes reality. Furthermore, agenda setting captures the way in which policy makers and power elite receive and then formulate (frame) science information, which are then presented by the media following their inbuilt structural framing devices.

The questions that agitate this study are these: to what extent are climate change issues captured by Nigerian national dailies? How is climate change framed in Nigerian newspapers? To what extent could the coverage and framing of climate change issues boost or constrain popular involvement in climate change discourse in Nigeria?

\section{Contextual Background}

\subsection{Deleterious Environmental Practices and Climate Change in Nigeria}

Generally and globally speaking, climate change issues have been on the front burner for some decades. Climate change challenge.org (2012) provides us with the following insights:

Climate change is produced by several factors namely: burning of fossil fuels, changes in land use through agriculture and deforestation; carbon dioxide, methane, nitrous oxide (and greenhouse gases) emissions.

Global warming affects crops adversely because of extreme weather conditions - drought, windstorms, floods, etc.

The major man-made causes of climate change come from 4\% carbon emission from industrial processes, $7 \%$ from agriculture, $21 \%$ from transport and $65 \%$ from fuel that generates electricity.

Agriculture alters the earth's land cover affecting the earth's capacity to absorb or reflect heat and light from the sun. Also, deforestation, desertification, and the use of fossil fuels are the main human induced carbon dioxide emissions. Whereas, rainforests absorb $20 \%$ of man-made carbon dioxide emission, deforestation is a very significant contributor to the causes of climate change. Deforestation allows $7 \%$ extra greenhouse gas to build up in the atmosphere whereas forests act as carbon sinks. They alleviate climate change by converting carbon dioxide to carbon during photosynthesis.

Climate change has the major effect of warming up the globe and produces other impacts such as increased cyclone intensity, melting of polar iceberg and glacier, increased salinity, sea level rise, inundation of low lying cities and coral bleaching. Other impacts include mortality of coral reefs, colonisation by invasive species, species migration, changes in ecosystem, mass extinction, ozone layer depletion, water shortages, and spreading of diseases.

The relevance of the above-mentioned facts is that Nigeria, being a contributor to climate change cannot escape the effects of climate change. This makes the discourse on climate change both at political and media circles cogent and important now.

Speaking of Nigeria's environmental situation specifically, Mongabay.com (2012) cites the UNFAO Report (2005) as providing the following indices on Nigeria as they relate to the environment and climate change:

Nigeria flares more gas than any other country. Methane produced from gas flaring is said to be 64 times as active a greenhouse gas as carbon dioxide.

Nigeria has one of the highest rates of forest loss (3.5\%) in the world. The country is said to have lost some 6.1 million hectares or $35.7 \%$ of its forest cover since 1990 . Sadly too, between 2000 and 2005, Nigeria is reported to have lost $79 \%$ of its old growth forests and is losing since $2000,11 \%$ of its primary forest annually. Deforestation and environmental degradation generally cost Nigeria six billion US dollars every year as timber concession are granted indiscriminately and oil palm plantations replace national forests. 
Additionally, Odiogor (2010) enlightens us some more about the situation:

The Sahara desert is advancing southwards at the rate of $6.0 \%$ per year. Nigeria loses about 350,000 hectares to desert encroachment. This has displaced communities in 11 states in the North and Nigeria loses 5.4 billion US dollars yearly as a result of drought and desert encroachment.

Climate change in the North of Nigeria poses a threat to national security and poverty alleviation. Forty two million people are affected in Adamawa, Borno, Bauchi, Gombe, Yobe and other North western states are under serious impact of harsh climatic conditions. The effects come in the form of gradual disappearance of arable lands, steady decline of food production; plant, animal, and human mortality, dislocation of farming and nomadic communities due to soil erosion, rain shortage, drought and worsening poverty; and drying up of surface and underground water.

While the rate of deforestation in Nigeria occurs at $4000 \mathrm{~km}^{2}$ per year, reforestation rate is a mere $10 \mathrm{~km}^{2}$ per year. Nigeria has $9.9 \%$ of its land area as protected forest i.e. 9.1 million $\mathrm{km}^{2}$ of total protected forest area and only $4 \%$ of tropical rainforest remain untouched (Dada, Jibrin, \& Ijeoma, 2006).

These facts and statistics highlighted above show how important it is for stakeholders in Nigeria including but not limited to government, policy makers, the media and environmental activists to initiate, sustain, and heighten ideas and actions directed at reducing the effects of climate change in Nigeria.

\subsection{Print Media Landscape in Nigeria}

In its Guide to the Nigerian Media, the Communications Unit of UNDP Nigeria (Undated) provides useful information on the history, character and slant of the media in Nigeria. According to it, the first Nigerian newspaper, Iwe Iroyin was set up by a British missionary in 1859. Today there are scores of news publications owned by government, communities but mostly by private persons. They come in tabloid format and published daily or weekly. Apart from news publications, there are others devoted to lifestyle, celebrity gossip, football, business, etc.

Based on factors such as traditions, geo-political outlook, ownership, and readership orientations, this study selected The Guardian, ThisDay, Punch and Daily Trust for examination. The Guardian is based in Lagos and is regarded as the leader of the Nigerian press. Established by the business mogul from the Niger Delta, the Late Chief Alex Ibru, the paper is serious, liberal, sober, and respected for its coverage of politics, business, arts, and sports. Its appeal is to the elite and the middle class.

ThisDay is also based in Lagos and was established by Mr. Nduka Obaigbena also from the Niger Delta. It is strong in the areas of business and political news and is renown for its sharp analyses and commentaries. It targets the upper and the middle classes. Its orientation is capitalist, the outlook is trendy and it is well known for breaking news, back-page columnists, and layout.

Punch is one of largest circulating newspapers in Nigeria. It is based in Lagos. Its owner was the Late Chief Olu Aboderin from Nigeria Southwest. The paper's strengths are its boldness, extensive operations, impressive colour production, sports, politics, entertainment and Yoruba agenda.

Daily Trust is owned by some Northern Nigerians and operates from the nation's capital, Abuja. It represents the interest of the Islamic North and is well-known for its back page columns.

\subsection{Climate Change, Impact of Media Coverage and Public Perception in Nigeria}

There is an apparent important link between how the public perceive climate change and the impact of media coverage in Nigeria. A British Broadcasting Corporation (BBC) research report (2008) draws attention to this linkage. The study asked what people in Nigeria thought about climate change and if communication and media strategies can be fashioned to aid Nigeria's response to climate change. Some of the findings of that study were as follows:

Nigerians tended to believe strongly that they were personally and collectively responsible for local environmental and weather changes.

The Nigerian respondents were not aware that present and future climatic problems have causes beyond Nigeria.

Nigerians use existing knowledge and beliefs to explain the effects of climate change.

Religion plays some role in environmental management. People view climatic changes as acts of God while religious leaders call on people to protect God's creation.

Opinion leaders, government, officials and non-governmental organisation representatives, social group leaders, religious leaders and traditional rulers are better informed about the global causes of climate change. 
In the three major Nigerian languages - Igbo, Hausa, and Yoruba there is a lack of standard translation and understanding of climate change terminology.

People in Nigeria mainly acquire information on climate change from the media and schools. However, there is a knowledge deficit in the media making audience education ineffective.

Nigeria focuses mainly on mitigation strategies as opposed to adaptation programme.

The knowledge of these facts is critical if the media and government are to take action which may bring solutions to the climate change problem.

\section{Review of Related Literature}

\subsection{Coverage, Discourse and Framing of Climate Change Issues in the Media and Newspapers}

Climate change is a global issue that is worrisome for people everywhere. One of the social institutions that are expected to also reflect this worry is the mass media, like other social institutions such as educational institutions, government agencies, NGOs and CBOs, international organisations, communities, etc. the mass media's importance in climate change discourse can obviously be viewed from the perspective of framing, magnifying and generally influencing social cognitions which in turn may influence actions and policies relating to climate change positively or negatively.

In an analysis of media reporting of the environment, Boykoff (2009) x-rayed factors that shape media coverage in a complex, dynamic and non-linear way. To Boykoff, the media are part of the wider cultural politics of the environment or the complex process through which environmental messages are produced, processed and consumed. This means, the mass media have to navigate through an avalanche of sources, information, influences, etc. to provide news to the public.

In the newspaper coverage of wild fire incidences in the U.S., Neuzil (2008) argues that media coverage of the environment in general have gone through two distinct stages. The first stage was when newspapers covered the environment only when they are part of the disaster or corporate misdeeds. The second stage, on the other hand, was when environmental beats became firmly established as a result of some social, economic and cultural factors that encouraged massive attention to environmental issues.

On newspaper portrayal of climate change science, Boykoff and Mansfield (2007) analysed four selected United Kingdom tabloid newspapers from 2000 to 2006 using content analysis and triangulated it with interviews with reporters and editors. The result of the coding of the 974 articles using the Lexis-Nexis database showed that for each of the seven years (2000-2006) the majority of the newspaper reports coded depicted emphasis on anthropogenic climate change.

Mare (2011) studied Southern African newspapers and found that climate change reports tended to generalise impact, were that climate change reports were not reflective of urgency, dismal ( $1 / 2$ percent of $1 \%$ environment reports), negative, event-based, official centred, and buried in the inside pages. The reports also give little South African context, were framed as a duel between North and South nations, were foreign sourced, biased against women, and shut out common people.

A major strategy for analysing media is to look at how contents are framed. Carvalho (2007) states that framing which is common among North American scholars shares comparison with discourse analysis. However, framing is more about categorisation (largely quantitative), and organisation around central ideas or perspectives or calling attention to some aspects of reality against others.

Numerous analyses of media content on climate change or global warming were also made using frame analysis. Boykoff (2007) in the analysis of television news from 1995 to 2006, found out that the media framed discussion about climate change science as 'contentious' despite the consensus of the scientific community. Boykoff (2007) then suggested that reporters ignore climate skepticism as the solution to such frames that end up confusing the public on climate science.

In addition, Olausson (2009) used qualitative critical discourse analysis (CDA) to examine how Swedish newspapers framed responsibility and collective action on global warming for local, national and international governance. Results showed that the Swedish media framed global warming as a social problem; with collective action pointing more to mitigation than adaptation; and action is seen more from the transnational or international angle; and that global warming is also framed with certainty of being anthropogenic. Olausson concludes that despite the familiar understanding that the media are tied to the policies of their nation-state, the Swedish newspapers were able to expand beyond their borders on global warming. 
De Vreese, Semetko and Valkenburg (1999) found that five frames constantly recur in newspaper coverage of global warming or climate change. These are conflict frame, human interest frame, responsibility frame, consequences frame and morality frame. However, just as newspapers do frame climate change or global warming stories, Hope (2009) found out that they have the capacity to also reframe stories. Hope reported that a US regional press framed a gas drilling project in Delaware initially as an economic benefit despite the open concern of environmentalists. However, due to accidents and hazards that the project resulted to, the press reframed the project as causing water contamination to the project area. The reframing helped in canceling the entire project.

\section{Theoretical Framework: Framing, Discourse, and Agenda Setting on Climate Change}

Theories permit us to evaluate and understand our world. Scientific theories allow objective description and explanation of events (Baran \& Davis, 1995). Besides, theories organise experience, extend knowledge, stimulate further research and perform an anticipatory function (Infante, Rancer, \& Womack, 1997). To Milstein (2009), environmental communication theory is based on the assumption that, our communication has a powerful effect on the way we perceive our environment. To this end, in media studies of environmental communication, framing theory is frequently used to examine media coverage of the environment. This is also true of agenda setting theory.

Hansen (2010) cites Gatlin (1980) as defining frames as, "principles of selection, emphasis, and presentation composed of little tacit theories about what exists, what happens, and what matters". Hanson also cites Entman (1993) as stating that framing is to, "select some aspects of a perceived reality and make them more salient in a communication text, in such a way as to promote a particular problem definition, causal interpretation, moral evaluation and/or treatment recommendation for the item described" (p. 190).

This explanation becomes even clearer where Nisbet (2009) states that framing interprets the story and sets a specific train of thought in motion. Frames tell why an issue is a problem, the causes, and the solutions. Nisbet states further: that audiences rely on frames to understand and discuss an issue; journalists use frames to write interesting and appealing news reports; policy makers apply frames to define policy options, reach decisions and experts employ frames to simplify technical details and make them persuasive. Nisbet maintains that in communicating climate change, frames do matter a lot for public engagement. He identifies the following frames in his typology of frames applicable to climate change: Social progress, (b) Economic development and competitiveness, (c) Morality and ethics, (d) Scientific and technical uncertainty, (e) Pandora's box/runaway science, (f) Public accountability and governance, (g) Middle way/alternative path, (h) Conflict and strategy and (i) Public health frame.

Social progress refers to improvement of life and being harmonious with nature. Economic development and competitiveness connote economic investment or market benefit. Morality and ethics concern rights and wrongs, scientific and technical uncertainties seek to know what is scientifically confirmed and what is alarmist, expert understanding and consensus. Pandora's box/runaway science reflects the need for action to avert catastrophe. Public accountability and governance are about research or policy in the public interest or serving special interests. Middle way is reflective of the approach in between conflicting and polarised opinions; while conflict and strategy capture the tussle among elites, personages or groups.

Some parallels can be seen between Nisbet's typology of frames and Lassen et al. (2011) grouping of recent discourses on climate change. Discussing the role of citizen participation in climate change discourse, they suggest that three discourses are especially prominent. These include discourses of (a) ecological modernisation, (b) green governmentality (c) civic environmentalism. Beyond discourse, opinions, and perception are important, for discourses are grounded in knowledge, attitudes, opinions and perceptions. Lorenzoni and Hulme (2009) studied the views of lay people in England and Italy concerning climate change and found four categories of views: Denying, (b) Doubting, (c) Uninterested and (d) Engaged. Denying sees climate change as unimportant and that human beings have no effect on it. Doubters consider climate change as important though not human-induced. The uninterested accept human role in climate change but wish to do nothing about it. The engaged, view climate change important enough, to act. The import of all these is that for journalists to set meaningful agenda and frame climate change issues appropriately, issues should be addressed for disparate public groups based on their needs, beliefs and attitudes.

Closely related to the framing theory is the agenda building or agenda setting theory. First explained by McCombs and Shaw (1972), Hansen (2010, p. 184) states that it, "refers to the power of the media to influence public perception of the relative prominence and importance of different events and actors/agencies". Agenda setting function means the capacity of the media to tell us what issues are important (Infante, Rancer, \& 
Womack (1997). That is to say, the media provide us with impressions of the outside world so that we can form impressions within us. We thus rely on the media to allow us experience what we have not encountered in the physical realm. However, the media do not present us with thoughts but furnish us with what to have thoughts about such as climate change issues.

To this end, Mare (2011) explains that in modern societies, the media are an indispensable avenue of obtaining information and are crucial in moulding awareness and concern as far as climate change issues go. This role is critical in setting the public agenda. Mare further states that the news media are a civic arena that stimulates diverse discourse of public affairs, a major medium where the meanings of public issues are produced, reproduced, and transformed. Besides, the media are important for us to appreciate risks, responsibilities, and the functioning of the polity. Finally, because of the capability of the media to educate, Mare (2011, p. 8) concludes that, "the media sector is often seen as having a special responsibility in promoting development communication, disaster warning and disseminating information to the most at-risk communities in the context of climate change".

For the Nigerian media, knowledge of these theories is germane to the coverage of climate change issues. By addressing themselves to the problem of climate change, newspapers can frame issues around solutions and ways in which people, governments and communities can act. According to Biello (2007), some of these include limiting population growth to check pressure on land, curtailing the cutting down of trees, disconnecting electrical appliances when not in use to conserve energy, consuming and buying less, being more efficient and avoiding wastage of electricity, water, fuel, etc. Other measures include reduction of greenhouse gas emission through burning of bush, coal, oil, and natural gas; infrastructure upgrade, construction of energy efficient buildings and possibilities of cleaner, alternative fuels.

Nigerian newspapers can also scale up their coverage as well as engage in framing of climate change issues in terms of what communities can do. Benfield (2012) suggests that communities can bring more vegetation into neighbourhoods, plant city scaled community gardens, adopt drought resistant landscaping, and use light-coloured roof and pavement to reflect heat and avoid building in low-lying parts of coastal areas.

Finally, whether for newspapers or other pro-environmental change agents, where the purpose is, to promote concern about climate change, encourage altering behaviours that threaten the climate, or compel policy makers to formulate green intervention, White (2010) suggests as follows and Nigerian newspapers should consider:

Being honest and forthright about the probable impacts of climate change and the magnitude of the challenge confronted.

Being clear and truthful about the impact of mitigating and adapting to climate change for current lifestyles.

Avoiding emphasis on painless, easy steps, over emphasising the economic opportunities that climate change mitigation and adaptation may provide, and the opportunities of "green consumerism" as a response to climate change.

Promoting pro-environmental social norms and recognise the power of social networks.

In using language moving away from conceptual frames (use of catch phrases, slogans, and clever spin) to deep frames (forging the connections between a stated position and a set of deeper values or principles such as preserving the integrity of natural areas as of right.

Promoting and encouraging demonstration of public frustration at the limited pace of government action.

\section{Method}

This study involved content analysis of four national dailies in Nigeria namely: ThisDay, Daily Trust, The Guardian and The Punch from January 2007 to December, 2009. The study universe was 4,380 issues of the four newspapers selected for reasons of availability, regularity of publication, wide distribution/circulation and relevant content in addition to ownership and geopolitical focus. The period chosen coincided with the increased tempo of activities and discourse on climate change, both nationally and globally. The systematic sampling technique was adopted in selecting $10 \%$ of the population. The newspaper article constituted the unit of analysis and the coding sheet the instrument of data collection. The parametres for coding included frequency of climate change coverage, format of presenting climate change articles, the content categories included climate change issues in Nigerian newspapers, framing of climate change in Nigerian newspapers, and sources of climate change reports. The data obtained from newspaper content analysis are presented in tables and analysis done in percentages and interpreted based on research objectives. 


\section{Results}

The findings obtained from the study are presented as follows:

Table 1. Frequency of reports on climate change in Nigerian newspapers

\begin{tabular}{lcc}
\hline Newspaper & Frequency & Percentage (\%) \\
\hline ThisDay & 25 & 18.7 \\
Daily Trust & 45 & 33.6 \\
The Guardian & 47 & 35 \\
The Punch & 17 & 12.7 \\
Total & 134 & 100 \\
\hline
\end{tabular}

Table 1 above shows that from 1st January, 2007 to 31st December, 2009, the four selected dailies covered a total of 134 items on climate change in the 438 issues sampled. As can be seen in the table, The Guardian provided more reports on climate change with 47 (35\%) of the reports. The Daily Trust had 45 reports equivalent to $33.6 \%$ ThisDay and The Punch followed with 25 (18.7\%) and $17(12.7 \%)$ respectively. It is evident from Table 1 that the newspapers gave a basis for awareness on climate change issues to their readers. A further break down of the data also shows some difference on year by year basis as can be seen on Figure 1 .

\section{Climate Change Items}

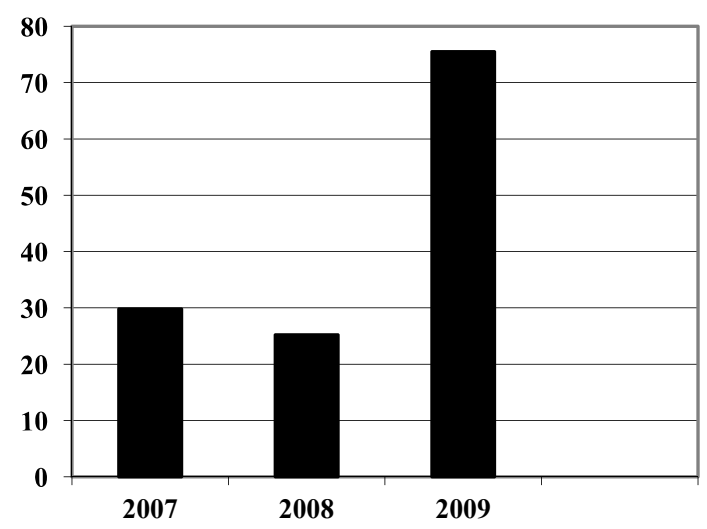

Figure 1. Yearly breakdown of Nigerian newspaper climate change items

Figure 1 shows that in 2007 and 2008 the total coverage for climate change items in the four selected newspapers was 31 and 27 respectively. However, the number of items shot up dramatically to 76 in 2009 . While the first two years share resemblance quantitatively; the third year suggests a marked increase in the number of climate change items.

Table 2 shows that out of the 134 reports on climate change in the four selected dailies, 82 (61.2\%) of the reports related to the politics and economics of climate change. The science and technology of climate change had 25 stories $(18.7 \%)$. The third in the reports were the socio-cultural issues relating to climate change which accounted for $13(9.7 \%)$. Natural climate activities were the fourth category with 8 items $(5.9 \%)$ and the fifth was the "other" category which accounted for 6 items equivalent to $4.5 \%$. The next table presents data on the issues in the newspaper items coded. 
Table 2. Issues in the Newspaper reports on climate change

\begin{tabular}{lcccccc}
\hline Newspaper & $\begin{array}{l}\text { Natural } \\
\text { Climate } \\
\text { activities }\end{array}$ & $\begin{array}{l}\text { Climate } \\
\text { science/ } \\
\text { technology }\end{array}$ & $\begin{array}{l}\text { Politics/ } \\
\text { econs }\end{array}$ & $\begin{array}{l}\text { Socio } \\
\text { cultural } \\
\text { issues }\end{array}$ & Others & $\begin{array}{c}\text { Column total } \\
25\end{array}$ \\
\hline ThisDay & 1 & 4 & 15 & 4 & 1 & 45 \\
Daily Trust & 4 & 10 & 27 & 3 & 1 & 47 \\
The Guardian & 2 & 9 & 28 & 4 & 4 & 17 \\
The Punch & 1 & 2 & 12 & 2 & 0 & $134(100 \%)$ \\
Total & $8(5.9 \%)$ & $25(18.7 \%)$ & $82(61.2 \%)$ & $13(9.7 \%)$ & $6(4.5 \%)$ & \\
\hline
\end{tabular}

From Table 2, it can be observed that the dominant issue in the Nigerian newspapers reportage of climate change was the politics and economics of climate change. A typical example is a story reported in The Guardian, June 26, 2009 p.10 which in the story, Meles Zenawi, the Ethiopian Prime Minister advocates that Africa be compensated for climate change.

Table 3. Frames of newspaper reports on climate change

\begin{tabular}{lcccc}
\hline Newspaper & Adaptation N (\%) & Mitigation N (\%) & Neutral N (\%) & Total (\%) \\
\hline ThisDay & $2(1.5 \%)$ & $13(9.7 \%)$ & $11(8.2 \%)$ & $26(19.4 \%)$ \\
Daily Trust & $4(3 \%)$ & $29(21.6 \%)$ & $11(8.2 \%)$ & $44(32.8 \%)$ \\
The Guardian & $9(6.7 \%)$ & $23(17.1 \%)$ & $15(11.2 \%)$ & $47(35.1 \%)$ \\
The Punch & $2(1.5 \%$ & $9(6.7 \%)$ & $6(4.5 \%)$ & $17(12.7 \%)$ \\
Total percentage & $17(12.7 \%)$ & $74(55.2 \%)$ & $43(32.1 \%)$ & $134(100 \%)$ \\
\hline
\end{tabular}

Table 3 shows that, the dominant frame of climate change in Nigerian newspapers is mitigation. The frame of climate change mitigation accounted for a little more than half of the coding for framing i.e. $74(55.2 \%)$. In the newspaper items, mitigation is framed by using such terms as 'alternative energy', 'mitigate/mitigation,' 'reduce the effects', 'carbon reduction/capture' 'carbon efficiency' 'emission reduction', 'carbon trading', etc.

The frame of mitigation in Nigerian newspapers was followed by the neutral frame which accounted for 43 (32.1\%) items and the last frame, adaptation, accounted for 7 (12.7\%) items respectively. In the neutral frame, the newspaper items serve the main propose of enlightenment through providing information about the climate change issues. The selected newspapers also framed adaptation with terms such as 'disaster preparedness', 'adjusting to climate change' 'adaptation', 'adapt to climate change', 'cope with changes occasioned by climate change', etc.

Sources of reports on climate change in this study were divided into two published newspaper reports from stories, events, opinions or people within Nigeria (domestic), on the one hand; and the ones from outside the country (foreign), on the other hand. Table 4 presents the details.

Table 4. Sources of Nigerian newspaper reports on climate change

\begin{tabular}{lccc}
\hline Newspaper & Within Nigerian (\%) & Outside Nigerian (\%) & Total (\%) \\
\hline ThisDay & $9(6.7 \%)$ & $16(11.9 \%)$ & $25(18.6 \%)$ \\
Daily Trust & $17(12.7 \%)$ & $28(20.9 \%)$ & $45(33.6 \%)$ \\
The Guardian & $20(14.9 \%)$ & $27(20.2 \%)$ & $47(35.1 \%)$ \\
The Punch & $3(2.2 \%$ & $14(10.5 \%)$ & $17(12.7 \%)$ \\
Total percentage & $49(36.6 \%)$ & $85(63.4 \%)$ & $134(100 \%)$ \\
\hline
\end{tabular}


The majority of climate change reports in the selected newspapers came from events outside the country i.e. 85 items or $63.4 \%$. This means, a smaller number of reports emanated from within the country i.e. 49 or $36.6 \%$. A larger number of the reports were not only based on foreign events but (some) were also culled or sourced from foreign news agencies or media.

Table 5. Genre of newspapers reports on climate change

\begin{tabular}{lcccccc}
\hline Newspaper & $\begin{array}{c}\text { Straight News } \\
(\%)\end{array}$ & $\begin{array}{c}\text { Feature } \\
(\%)\end{array}$ & $\begin{array}{c}\text { Opinion/editorial } \\
(\%)\end{array}$ & $\begin{array}{c}\text { Interviews } \\
(\%)\end{array}$ & $\begin{array}{c}\text { Others } \\
(\%)\end{array}$ & Total (\%) \\
\hline ThisDay & $20(14.9 \%)$ & $4(3 \%)$ & $1(0.7 \%)$ & $0(0 \%)$ & $0(0 \%)$ & $25(18.6 \%)$ \\
Daily Trust & $37(27.6 \%)$ & $5(\%)$ & $3(2 \%)$ & $0(0 \%)$ & $0(0 \%)$ & $45(33.6 \%)$ \\
The Guardian & $41(30.6 \%)$ & $4(3 \%)$ & $2(1.5 \%)$ & $0(0 \%)$ & $0(0 \%)$ & $47(35.1 \%)$ \\
The Punch & $14(10.4 \%$ & $1(1 \%)$ & $2(1.5 \%)$ & $0(0 \%)$ & $0(0 \%)$ & $17(12.7 \%)$ \\
Total & $112(83.6 \%)$ & 14 & $8(5.9 \%)$ & $0(0 \%)$ & $0(0 \%)$ & 134 \\
percentage & & $(10.4 \%)$ & & & & $(100 \%)$ \\
\hline
\end{tabular}

Table 5 above is on the genre of newspapers reports on climate change. The data show that the most predominant genre of report on climate change in the selected newspapers was the straight news format, which was as high as $112(83.6 \%)$. This is distantly followed by features which accounted for 14 items, equivalent to $10.4 \%$. The third genre was opinion/editorial which accounted for 8 items equivalent to $5.9 \%$. Interviews and "other" categories had zero items. In all, the non-straight news genre (features, editorials, opinions, interviews) accounted for only $16.4 \%$ of climate change reports. This shows that climate change reportage was largely in the genre of news with the lack of depth associated with it.

\section{Discussion of Findings}

The following discusses the findings of the study in relation to the objectives of the study.

\subsection{The Frequency of Reporting Climate Change Issues in Nigerian Newspapers}

As shown earlier, Figure 1 also highlights the fact that the level of climate change reporting or coverage especially in newspapers fluctuates from time to time. Explanations for this cyclical pattern of newspaper reportage of climate change spawned the 'issue attention cycle' model by Downs (1972); 'public arena' model (Boykoff \& Boykoff, 2007) and 'circuit of culture' model (Cavalho \& Burgess, 2005). It is instructive to note here that the coverage of climate change in Nigerian newspapers shot up in 2009, the year of The United Nations Climate Change Conference in Copenhagen took place.

The data show that the four newspapers: Thisday, The Guardian, Daily Trust and The Punch provided a total sum of 134 items on climate change within the three year study period i.e. 2007-2009. Therefore, it can be said that climate change issues can be regarded as being on the threshold of public agenda. That is, it is still trying to gain momentum so as to reach a level where it may cause a rise in public concern and subsequent action. Boykoff (2009) found out that there is less coverage of global warming or climate change in newspapers published in South America and Africa compared to Europe, North America, and Asia. This, points to a critical information gap in reporting on this issue.

\subsection{The Dominant Issues in Newspaper Reportage of Climate Change in Nigeria}

The data presented in Table 2 show that the most dominant issue with $61.2 \%$ of the coded reports on climate change in Nigerian newspapers pertained to the politics/economics of climate change. This is an indicator that newspaper reporting of climate change in Nigeria is predominantly about agreements, meetings, funds, governance and related matters. Natural or bio-physical climate change occurrences such as heat waves, floods, ocean surges, desertification, drought, etc are less frequently reported. Also, less reported are issues relating to climate science and socio-cultural issues relating to climate change. With regard to the imbalance of coverage, Shanahan (2000) argues that less coverage of science in climate change reportage is because science is no longer the basis for interest on the issue while politics, economics and international relations are.

As important as the peripheral issues are to reporting climate change, Nigerian newspaper readers could have been served better if the issues are relatively balanced as climate change hinges a lot on what people know. 
Knowing what to do in relation to floods, droughts, heat waves, sea level rise, etc. can be very helpful to newspaper audiences from avoiding impacts to initiating actions in mitigation or adaptation.

\subsection{Frames with Which Newspapers Report Climate Change in Nigeria}

Data presented on Table 3 show that 74 (55.2\%) of the coded newspaper reports on climate change were framed in terms of mitigation. While adaptation frame got only $17(12.7 \%)$, the rest of the reports were neutral being mainly informative and neither emphasising adaptation nor mitigation. While Nigeria is located in the southern hemisphere which is experiencing more climate change effects for which adaptation has been seen to be the first line of response (NEST, 2001; NEST/GCSI, 2004), Nigerian newspapers have largely framed climate change in terms of mitigation. It has been argued that mitigation is largely the business of developed countries that have historic responsibility (due to their earlier and advanced level of industrialisation, they are the largest carbon emitters) and the capacity to shoulder more of the burden of climate change solution while developing countries should receive assistance (Billet, 2009). Also, adaptation to climate change is considered especially relevant for developing countries, where societies are already struggling to meet the challenges posed by existing climate variability and are, therefore, expected to be the most adversely affected by climate change (McCarthy et al., 2001).

In this context, climate change framing in Nigerian newspapers, as found out this study, can be said to be composed with unintentional frames. According to Konig (2004) unintentional frames are not consciously manufactured but unconsciously adopted in the course of communication. The Nigerian newspaper journalists may not have fully appreciated the complexity and dimension of climate change for them to frame the issue largely in terms of mitigation rather than adaptation which should have been the first line of response.

\subsection{Sources of Information in Newspapers on Which Climate Change Issues Are Based}

Data presented in Table 4 show that most of the climate change reports in Nigerian newspapers are from events outside the country i.e. 85 items or $63.5 \%$. This indicates that climate change issues in Nigeria are largely a regurgitation of international news in form of news agency reports or culled from foreign media. This confirms Boykoff and Simons' (2007) finding. This also suggests that the agenda set by Nigerian newspapers is based on external concerns of climate change and not internal ones. The focus of reportage in national newspapers should be climate change issues occurring in the country or as they may affect the country.

\subsection{Genres through which Climate Change Issues Are Presented in Nigerian Newspapers}

Data presented in Table 5 show that climate change report is dominated by straight news genre: as high as 112 $(83.6 \%)$. This is a pointer to the fact that climate change is reported in a shallow manner with few avenues for the readers to be exposed to the background of the complex issues. While news heralds events or issues, the background to the issues can usually be found in news features, editorials/opinions, and interviews.

In response to the quality of climate change reports which is reflected in the dominance of episodic and brief news format, Boykoff (2009) argues that the role of the journalists is not that of a repeater of occurrences or a parrot but they should be able to provide additional information, interpretation and contexts to issues being covered, especially complex issues such as climate change. This is important because the agenda that is not clearly articulated by the presenters may likely not receive appropriate interpretation/discussion and action. For news format to dominate climate change coverage in Nigeria newspapers suggests that the quality of newspaper reportage is low which in turn could be as a result of weak understanding of the issue.

\subsection{Content/Discourse of Nigerian Newspaper Articles on Climate Change}

An examination of a few headlines and leads of the 134 newspaper stories on climate change in Nigeria presents some of the interesting revelations indicated in the previous section. On December 22, 2009, ThisDay had a the story: "China to blame for Copenhagen failure." The story was attributed to the British Secretary of State. This is an example of a story sourced from outside Nigeria. On September 23, 2009, ThisDay again featured a headline; "UN Climate Summit puts China, India in spotlight"- another example of a focus away from Nigeria. Much earlier, on December 2, 2009, with the headline: "Nigeria: Climate Change and Curse of Oil, ThisDay reported on the second national consultation on the environment held in Port Harcourt. This reflects the finding as did others, that climate change reports are often incidental or event-based, not routine reports. Of the three reports, one bore a sizeable picture of gas flare.

On its part, Daily Trust on May 6, 2009 had the headline: "JNI tasks government on climate change". In the article, a state branch of Jama'atu Nasir Islam urged governors in northern Nigeria to provide alternative sources of energy for cooking to curb the threat of deforestation and the adverse effects of drought. This story reflects the link between religious leaders and the concern for the environment. It is sourced from within Nigeria but bears a 
photograph of the Liberian President engaging in environmental sanitation. Later on December 22, 2009, Daily Trust, had an editorial on, "The Climate change Summit." The editorial called on Nigeria and Africa to take action to counter the effects of global warning. This is another story based on an incident - Copenhagen summit and framed in terms of mitigation.

Also, The Guardian on May 26, 2009 had the headline: A return to rail system will help climate change. Attributed to a Nigerian academic, the story is framed on the basis of mitigation. So is the one entitled: "Zenawi wants Africa compensated for climate change", published June 26, 2009. These stories carried no photographs or infographics.

For the Punch newspaper, the two examples here are still reflective of foreign sourced reports. In "Climate targets will kill coral", the source is the BBC. In another headline published April 25, 2009, Hillary Clinton is quoted as saying, "US ready to lead climate change fight. This story is also event-based and both are not accompanied by pictures or infographics. Similar findings and more were reported by Mare's (2011) study on media representation of climate change in southern Africa. He saw climate change reports as foreign sourced, politics based, lacking in local context, event-based, official-centred, negative, and under-covered.

\section{Conclusion and Implications for Public Participation in Climate Change Discourse}

The study does show that the analysed newspapers reported climate change issues at about 31 percent. This would constitute a media agenda that could influence both public and policy agenda on climate change. However, the media agenda were dominated by the politics and economics of climate change. For people and especially ordinary people to participate more and get more involved in climate change discourse, the narrative, discourse, frame and coverage of climate change issues must pay significant attention to natural climate change occurrences, socio-cultural issues, as well as climate science itself. These are narratives and discourses that individuals, communities, groups, farmers, fishers, drought affected, grazers, women, youths can readily identify with because they are personally and directly affected.

Secondly, as the study shows, framing climate change mainly in terms of mitigation (this occurred at the level of $55 \%$ ) shuts out a greater majority of people because the people are about helpless since they lack the funds, knowledge or other resources to mitigate. However, if climate change issues are framed more in terms of adaptation, this can readily permit more groups of people at family, community and national levels to engage in the discourse on climate change because they can take action such as tree planting or adopting new methods of farming, grazing, and fishing.

Thirdly, the study shows that the analysed newspapers sourced their reports mainly from outside the country to the tune of $63 \%$. This is a huge constraint on participation opportunities. Sourcing reports from within Nigeria would open up opportunities for Nigerian people to relate their experiences of climate change. Internal sourcing of reports would also allow newspapers to document what people and communities are doing to cope with climate change. It would equally allow groups, non-governmental organisations, community based associations, faith-based groups, environmental protection activists, donor groups, intergovernmental agencies the opportunity to voice their frustration; successes and challenges in climate change palliative activities.

Fourthly, the study shows that the dominant format with which the selected newspapers presented climate change issues was the news report format to the tune of 84 percent. This is another major constraint to participation opportunities. People particularly, common people participate in media discourses through letters to the editor, opinion articles, columns, interviews and vox pops. Newspapers themselves involve people and give more depth to the treatment of issues when they syndicate columns, present editorials and deliver in-depth analysis and features. For the commons to participate and get more involved in climate change discourse, newspapers must create copious avenues through the dedication of more newshole for letters, opinions, features, columns, interviews, vox pop, etc. Apart from monitoring the landscape and presenting climate change reports, this sort of role envisaged here is both supportive and collaborative. Only in this way can the media boost involvement and participation in climate change discourse. Climate change issues should be seen as a present problem that can be addressed with committed action by people, groups, communities and governments.

\section{Recommendations}

Based on the findings of this study, it is recommended that:

As Nigerian newspapers and journalists place emphasis on the politic and economic of climate change, equal if not more attention should be paid to climate change as it affect the lives, work, livelihood of Nigerians and all the activities they should engage in to adapt to climate change. 
Rather than concentrate on mitigation measures to address climate change effect, newspapers in Nigeria should, in keeping with the economic status of Nigeria, use their information mature channels to inform, educate, and disseminate knowledge about how the different sections of the Nigerian society can adopt climate change adaptation measures.

In sourcing for climate change or environmental information, newspapers and journalists in Nigeria should recourse to local, national and regional sources such as community people, government officials, experts, books, reports and other publications. Foreign experts, news agencies, and publications should serve as supplementary sources.

To give readers and other stakeholders more say, deeper involvement and greater participation in climate change issues; Nigerian newspapers should not limit the genre of the discourse to news. They should open up avenues for editorials, columns, opinions, interviews, and supplements.

It is believed that if these suggestions are followed, Nigerian newspapers would not only cover climate change issues as frequently as they are important, they would also give the diverse issues the deep breadth of perspectives they deserve, variegated genre and sourcing as would engender the participation and involvement of greater numbers of ordinary people and communities in the discourse on climate change; but would permit the press to frame climate change as a present problem that is amenable to solutions if people and communities are well informed and motivated to act in environmentally friendly ways.

All said, 20 years after the Rio declaration, at the Rio +20 conference, member states of the United nations in order to reduce the impact of climate change, made commitments to plant 100 million trees by 2017, green 10,000 square kilometres of desert, save one megawatt hour of electricity daily and empower 5000 women entrepreneurs in green economy business in Africa (tribune.com.org). By covering, framing, and offering greater opportunities for the commons to participate in the discourse of these solutions, Nigerian newspapers would have contributed immensely.

\section{References}

Baran, S. J., \& Davis, D. R. (1995). Mass Communication Theory: Foundation, Format, and Future. California: Wadsworth.

Benfield, K. (2012). What communities should do to protect against climate change. Retrieved June 11, 2012, from www.theatlanticcities.com/../1562/

Biello, D. (2007). 10 Solutions for climate change. Scientific American. Retrieved June 11, 2012, from www. scientificamerican.com/article.cfm

Billett, S. (2010). Dividing climate change: Global warming in the Indian Mass media. Climatic Change, 99, 1-12. http://dx.doi.org/10.1007/s10584-009-9605-3

Boykoff, M. T. (2007). From convergence to contention: United States mass media representations of anthropogenic climate change science. Transactions of British Geography, 32, 477-489.

Boykoff, M. T. (2009). We speak for the trees: Media reporting on the environment. Annual Review of Environmental Resources, 34, 431-457. http://dx.doi.org/10.1146/annurev.environ.051308.084254

Boykoff, M. T., \& Simmons, J. T. (2007). Media coverage of climate change: Current trends, strengths, weaknesses. UNDP Human Development Report 2007/3. Retrieved March 31, 2010, from www.undp.org

British Broadcasting Corporation World Service Trust. (2008). Nigeria talk climate. The public understanding of climate change. Retrieved January 6, 2013, from http://africatalksclimate.com/country/nigeria

Carvalho, A. (2007). Ideological cultures and media discourses on scientific knowledge: Re-reading news on climate change. Public Understanding of Science, 16(2), 223-43.

Carvalho, A., \& Burgess, J. (2005). Cultural circuits of climate change in U. K. broadsheet newspapers, 1986-2003. Risk Analysis, 25(6), 1457-1469.

Climate Change Challenge.org. (2012). Climate change. Retrieved from May 11, 2012, from www. climatechangechallenge.org

Dada, F. O. A., Jibrin, G. M., \& Ze Ijeoma, A. (2006). Secondary Atlas. Ibadan: Macmillan Nigeria.

De Vreese, Sametko, \& Valkenburg. (1999). The effects new frames on readers' thought and recall. Communication Research, 25, 550-569.

Downs, A. (1972). Up and down with ecology - issue attention cycle. Public Interest, 28, 38-50. 
Hansen, A. (2010). Environment, Media and Communication. London: Routledge.

Hope, D. S. (2009). (Re) framing environmental news: A case study of the gas-drilling controversy in the Catskills Delaware River watershed. In E. Seitz, T. P. Wagner, \& L. Lindefeld, (eds.), The Proceedings of the Biennial Conference on Communication and the Environment. Held at the University of Southern Maine, Portland, June 23-30. University of Maine, Dept. of Communication and Journalism: Portland.

Infante, D. A., Rancer, A. S., \& Womack, D. (1997). Building Communication Theory (3rd Ed). Illinois: Waveland Press.

Konig, T. (2004). Framing Analysis: A Primer. Retrieved from www.iboro.co.uk/research/methods/resources links/frames_primer.html accessed 26/11/2006

Lassen, I., Horsbol, A., Bonnen, K., \& Pedersen, A. G. J. (2011). Climate change discourse and citizen participation: A case study of the discursive construction of citizenship in two public events. Environmental Communication, 5(4), 411-427. http://dx.doi.org/10.1080/17524032.2011.616516

Lorenzoni, I., \& Hulme, M. (2009). Believing is seeing: Lay people's views of future socio-economic and climate change in England and in Italy. Public Understanding of Science, 18, 383-400.

Mare, A. (2011). Climate change mediation and mediatisation in Southern Africa: Towards climate and environmental journalism. Climate Change Symposium 2011. Retrieved July 17, 2012, from www.africaadapt.net/media/resources/55/panel\%207.pdf

McCarthy, J. J., Canziani, O. F., Leary, N. A., Dokken, D. J., \& White, K. S. (2001). Climate change 2001: Impacts, adaptation, and vulnerability. IPCC WGII contribution to the TAR, Cambridge: Cambridge University Press.

Milstein, T. (2009). Environmental Communication theories. In S. Littlejohn, \& K. Foss (Eds.), Encyclopedia of communication theory (pp. 344-349). Thousand Oaks. http://dx.doi.org/10.4135/9781412959384.n130

Mongabay.com. (2012). Tropical rainforests. Retrieved June 4, 2012 from http://rainforest.mongabay.com/20 Nigeriain.htm

Neff, R. A., Chan, I. L., \& Smith, K. C. (2008). Yesterday's dinner, tomorrow's weather, today's news? US newspaper coverage of food system contribution to climate change. Public Health Nutrition, 1-9.

Neimeyer, S., Petts, J., Hobson, K., \& McGrefor, G. (2004). Understanding thresholds in human behaviour and responses to rapid climate change. Working Paper 04/01. Centre for Environment and Human Behaviour Programme, The University of Birmingham.

NEST. (2011). Gender and Climate Change Adaptation: Tool for Community-Level Action in Nigeria. Ibadan: Nigeria Environmental Study/Action Team.

NEST/GCSI. (2004). Nigeria Climate Change: Executive Summary of Five Multi-Sector Surveys on Nigeria's Vulnerability to Climate Change. Ibadan: Nigeria Environmental Study/Action Team.

Neuzil, M. (2008). The nature of media coverage: Two Minnesota fires. Forest History Today, Fall 32-38.

Nisbet, M. C. (2009). Communicating climate change: Why frames mater for public engagement. Environment Science and Policy for Sustainable Development. Retrieved July 13, 2012, from www.environmentmagazine.org/ archive/backissues/ March-April 2009/Nisbet-full.html

Olausson, U. (2009). Global warming-global responsibility? Media frames of collective active action and scientific certainty. Public Understanding of Science, 18, 421-436. http://dx.doi.org/10.1177/0963662507081242

Shanahan, J. (2000). Cycles upon cycles. The evolution of media attention to global climate change. Paper presented at climate change communication conference, Waterloo, Canada.

Taylor, M. (2011). Framing climate change: How we lost 20 years of action. The fifth estate. Retrieved July 27, 2012, from www.thefifthestate.com.all/../8870

Tribune.com.ng. (2012). Riot 20 conference and its aftermath. Nigerian Tribune. Retrieved July 10, 2012, from tribune.com.ng/

Umejei, E. (2010). Climate change: Nigerian media sleeping on duty. Retrieved June 16, 2012, from emeka umejei. Wordpress.com/2012/01/0... 
United Nations Development Programme (UNDP). (Undated). Guide to the Nigerian Media. Retrieved June 18, 2012, from http://web.undo.org/comtoolkit/reaching-the-outsideworld/docs/Best\%20practices/A Guide to the Nigerian Media, pdf

United Nations Environment Programme (UNEP). (2012). Rio Declaration on Environment and Development. Retrieved June 16, 2012, from www.unep.org/documents/default.asp

Vanguard ngr.com. (2010). Special report on desertification in Nigeria: The sun eats our land by Hugo Odiogor. Retrieved June 14, 2012, from www.vanguardngr.com/2010/05/

White, F. J. (2010). How to communicate climate change information to the public. Citizen action monitor. Retrieved July 13, 2012, from http://citizenationmonitor.wordpress.com/2010/10/11

World Resources Institute. (2012). Principle 10 of the Rio Declaration. Retrieved June 16, 2012, from www.wri.org/publication/content/8078 